811.163.41'373.611:811.163.3'373.611 https://doi.org/10.18485/sj.2019.24.1.25

\author{
ЖАРКО С. БОШЫАКОВИТ * \\ ГОРДАНА Р. ШТАСНИ \\ Универзитет у Новом Саду \\ Филозофски факултет
}

Оригинални научни рад Примљен: 09. 10. 2018. Прихваћен: 15. 01. 2019.

\title{
АТРИБУТИВНЕ ИМЕНИЦЕ МОТИВИСАНЕ СОМАТИЗМОМ ГЛАВА У СРПСКОМ И МАКЕДОНСКОМ ЈЕЗИКУ И ЮИХОВИМ ДИЈАЛЕКТИМА**
}

У раду се испитују атрибутивне именице мотивисане лексемом глава у српском и македонском језику и њиховим дијалектима. Грађа показује да је највећи број деривата настао суфиксацијом, а знатно ређе композицијом. Суфиксали су углавном деривати првог или другог степена (глав-оња, гла-уч; празноглав-ац и празноглав-е; глава $a^{0}-$ глав-урда $a^{1}-$ главурд-ан $\left.{ }^{2}\right)$. Сложенице су различитог типа: а) Го + о + И (врт-о-глаја); б) Ио + о + Го + суфикс - глав-осек-Ø); в) Ио + о + И (глав-о-топ). Творба атрибутивних именица условљена је семантичким садржајем лексеме глава у основном значењу. То су компоненте које носе информацију о величини (главоњ, главуч, главок, glavan), функцији (празноглавац, празноглавеи), изгледу (седоглаваи), положају (кривоглавиле) ентитета именованог мотивном речју.

Са дериватолошког становишта посматрамо продуктивност суфикса који су заступљени у њиховој структури, као и конкурентност која се међу њима јавља (нпр. глав-аш и глав-оњ $a$ ). Такође се бавимо и статусом моционих образовања (myпоглав-ащ 'тупоглава мушка особа' и тупоглав-ка/тупоглав-ища 'тупоглава женска

*zarkobosnjakovic@ff.uns.ac.rs

** Рад је настао у оквиру два пројекта: Дијалектолошка истраживања српског језичког простора (178020) и Стандардни српски језик: синтаксичка, семантичка и прагматичка истраживаға (178004), која у целини финансира Министарство просвете, науке и технолошког развоја Републике Србије. 
особа'), као и нијансирањем атрибутивног значења које је условљено денотатом (гологлавац м 'онај који је голе главе; експр. сиромах', гологлавка ж 'женска особа која је без мараме на глави' и гологлавче с 'дете с ретком косом').

Са семантичког становишта указујемо на малобројне вишезначне атрибутивне именице чија су значења настала метафоризацијом (әлавоњ $а$ 1. пеј. а. 'човек велике главе'; б. 'главешина, старешина'; 2. терм. зоол. 'врста лептира, губар Lymantria dispar'; главуч 1. пеј. 'човек со голема глава'. 2. 'богат или влијателен човек; буџа'; 3. 'човек на висока позиција, функционер, директор'). Денотирајући особу, оне углавном имају негативну експресивну вредност и првенствено су одлика разговорног језика.

Кључне речи: атрибутивне именице, семантичко-деривациона анализа, српски језик, македонски језик, дијалекти

\section{1. УВОД}

1.1. Предмет истраживања и корпус. Основни предмет истраживања у овом раду представљају атрибутивне именице мотивисане соматизмом глава у српском и македонском језику и њиховим дијалектима. Деривати за стандардни српски преузети су из СДР (2003), а за македонски из ТРМЈ (2003-2015) и PMJ (2005). Грађа народних говора прикупљена је углавном из најобимнијих дијалекатских речника свих дијалеката српског језика. Македонски корпус формиран је на основу дијалекатских текстова. ${ }^{1}$ Основни методолошки приступ грађи је семантичко-деривациони и компаративни, а спроведен је с циљем да се утврде семантички и творбени механизми на основу којих се деривирају именице овога типа у оба посматрана језика, као и однос између стандардне и дијалекатске лексике.

1.2. Семантичко-деривационе карактеристике атрибутивних именица. Општа карактеристика деривираног именичког израза у језичком систему јесте његова номинациона функција. Будући да је реч о дериватима, тај сложени процес номинације заснива се на синтези појмовне вредности садржаној у творбеној основи мотивне речи и информацијама заступљеним у формантима који учествују у деривацији, при чему се, дакле, поред номинационе остварује и референцијална функција. Атрибутивне именице настају по истом семантичко-деривационом механизму и припадају обимној категорији општих именица, семантички веома разноврсних, с обзиром на сву разноликост ентитета које именују. Међу њима значајно место припада атрибутивним именицама са човеком као референтом. Номинација именица овог семантичког типа може бити подстакнута физичким изгледом човека и у том смислу соматизми имају важну мотивациону улогу. Они у својој појмовној вредности садрже квали-

\footnotetext{
${ }^{1}$ Речници народних македонских говора недоступни су па их стога нисмо могли укључити у изворе.
} 
тативне компоненте значења (величина, облик, функција, положај) које се асоцијативно поезују с људском природом, што представља основни услов за деривацију атрибутивних именица.

1.3. Атрибутивне именице мотивисане соматизмом глава. Како наводи Р. Драгићевић (2007: 75-76) најразвијенију значењску структуру „имају лексеме које се односе на човека - на делове тела, на храну коју једемо, на пића која често пијемо, и, наравно, на кућу у којој живимо". Лексеме које имају већи удео у парцијалној оцени човека показују да је пажња посматрача усмерена пре свега према човековој глави (главоња) и оним њеним деловима који су у комуникацији лицем у лице највише изложени погледу саговорника, па се најпре запажају (носоюа, зубоњ а, устою а, увоњ а, вратоња) (Вељковић Станковић 2016: 330). Поред тога, лексема глава представља централни соматски појам jep је њоме именован део тела од виталног значаја за живот човека. Она има богат семантички садржај који омогућава деривацију јединица различитог семантичког типа а међу њима атрибутивне именице заузимају важно место. ${ }^{2}$

Она је у РМС репрезентована с десет различитих семантичких реализација. Основно значење гласи 'горњи, округласт део човечијег или животињског тела у коме је мозак' 3 Декомпоновани садржај њене појмовне вредности садржи следеће компоненте: архисему (део човечијег или животиюског тела); диференцијалне семе: позиција (горњи), облик (округласт), посесор (човек или животиња), садржај (мозак). ${ }^{4}$ Сличну семантичку структуру лексема глава има и у македонском језику, у којем је забележно једанаест значења. ${ }^{5}$ У основној реализацији изостављене су компоненте положаја и облика главе, а садржана је соматска компонента и њен садржај 'дел од телото на човек или на животно во кој се наоѓа мозокот’.

${ }^{2}$ Деривати мотивисани лексемом глава припадају различитим појмовним доменима. „Најшири је обим телесног домена којим су обухваћене јединице чија се концептуална вредност односи на људско тело $(23,31 \%)$, а знатно је мање свих осталих. На човека као денотата односе се и домени карактера $(10,47 \%)$, те интелекта и стања свести $(9,45 \%)$. Дериватима се концептуализују и категорије деловања $(11,82 \%)$, кретања $(9,45 \%)$, управљања $(8,44 \%)$ и комуникације $(0,7 \%)$ јер сви они подразумевају човека као агенса, са изузетком глагола главати, који се односи на рибе. Ван људског су домени предмета $(13,17 \%)$, животиња и животињског тела $(9,45 \%)$ и биљака (5,5\%)" (Штрбац/Штасни 2017: 77).

${ }^{3}$ Остала значења су: 2. 'ум, разум, памет'; 3. 'живот'; 4. а. 'особа, појединац'; б. 'марвинче, грло'; 5. 'личност која руководи, вођа'; 6. 'почетни, предњи део чега'; 7. 'проширени или задебљали горњи односно крајњи део (ексера и др.)'; 8. 'комад (неког прехрамбеног производа у облику купе или лопте)'; 9. 'главица $(2,3)$ '; 10 . 'део (књиге или списа), одломак, поглавље; одељак'.

${ }^{4}$ Издвојене семантичке компоненте имају важну улогу у мотивацији секундарних значења лексеме глава, али то сада није наш предмет интересовања.

${ }^{5}$ Остала значења су: '2. ум, разум, мозок'; 3. 'животот на човекот'; 4. 'поединец, лице'; 5. 'животно'; 6. 'раководител, водач'; 7. 'дел од книга, поглавје, партија, оддел'; 8. 'долен дел од растение'; 9. 'горен, преден дел на предмет (клинец, шајка)'; 10. 'како мерка за висина'; 11. 'реверс на монета'. 
У оба језика деривацију атрибутивних именица с човеком као референтом иницирају компоненте значења имплицитно садржане у семантичком садржају лексеме глава. Оне носе информацију о величини (главоња, главуч, главок), функцији (празноглаваи, празноглавеи), изгледу (седоглаваи) и положају (кривоглавиле) ентитета именованог мотивном речју.

\section{2. КВАЛИФИКАЦИЈА ЧОВЕКА ПРЕМА СПОЉАШЬИМ СВОЈСТВИМА.}

2.1. Мотивационе компоненте. Именовање човека мотивисано компонентама 'величина и изглед/облик соматизма' представља системску појаву у деривацији атрибутивних именица, што посебно потврђује дијалекатска грађа у којој су готово сви соматизми мотивне речи (вратоња/вратло, шијан; мозгоња/мозган; челоња; окара; носара, носоња; ушља/ушан; кривоуст; трогрла; зубна, зубоња; бркача/бркна; бокоња; трбела/трбоња; дворебрач; прсача/сисача/ с́икна, прсоња; иоглан; рукавенда). У том погледу ни деривати с основом именице глава не представљају изузетак. Ове компонете су веома продуктивне како у стандарном језику тако и у народним говорима у оба посматрана језика.

2.1.1. Именовање човека према величини главе. Компонента која се односи на величину мотивног појма посебно је продуктивна јер се човек по правилу именује према деловима тела који су упадљиви, будући да су истуренији и већих димензија од нормалног (Штасни 2013: 116). ${ }^{6}$ Деривати овога типа заступљени су у свим јужнословенским језицима, па и у грчком језику: $\kappa \varepsilon \varphi \alpha \lambda$ - $\alpha \varsigma$ 'главоња, који има велику главу' (Г-СР). У српском и македонском језику и њиховим дијалектима ове именице настају углавном суфиксацијом, а само по изузетку слагањем.

Утицај творбене основе на лексичко значење атрибутивних именица огледа се у аналитичком изразу творбеног значења деривата односно њиховој парафрази. Тако код лексема типа главоња, носоња и сл. предикацију конституише глагол имати, који уз себе везује именичку синтагму с придевом велик као обавезним детерминатором, при чему именица денотира неки део тела" (Ајџановић 2007: 81). Међутим, забележени су и другачији типови парафразе: а) човек велике главе, б) човек са великом главом, што је уобичајено и у македонском ('човек со голема глава'), бугарском ('човек с голяма глава')

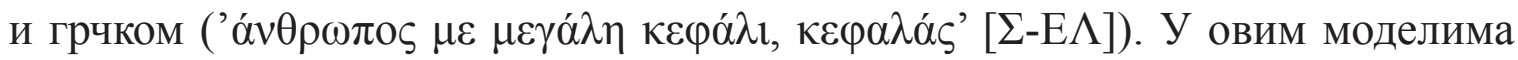

${ }^{6} \mathrm{O}$ значајном деривационом потенцијалу наведене семантичке компоненте сведоче и бројни аугментативи и пејоративи с лексемом глава у творбеној основи: главетина, главускера, главура, главурина, главурда, главусина, главуча, главуиа, главуша. 
носилац атрибуције је квалитативни генитив односно инструметал у синтагматској структури с именицом глава као управним чланом и придевом велик као обавезним детерминатором.

У значење деривата првог степена преноси се целокупан семантички

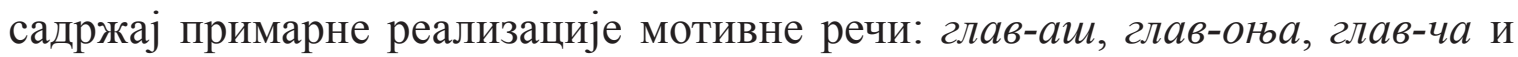
глав-иа.

Суфикс -аш се углавном везује за именичке основе (кикаш [РГГ], чираш [РГП]), ретко за основе соматизма (брадаш, главаш), а изведенице означавају људе. Суфикс -оља спада у суфиксе високе продуктивности у творби атрибутивних именица. Комбинује се с придевским (млакоња), ређе с глаголским основама (ждероюа), али је најплоднији у творби деривата с основом соматизма. ${ }^{7}$ Клајн (2003: 177) наводи да изведенице суфиксом -оюа означавају човека или животињу с особином исказаном у основи, те да могу бити са хипокористичним-шаљивим значењем, као у зекоюа, медоњ $а$, или се пак може радити о вулгаризмима. Он, међутим, не говори о дериватима с пејоративном димензијом, као у примерима главоља, носоюа и сл. Д. Вељковић Станковић (2016: 329) издваја групу деривата изведених суфиксом -оюа, чија се аксиолошка вредност заснива на парцијалној естетској основи, тј. на основу изгледа једног дела тела (зубоња, главоња, носоња и сл.). Клајн (2003: 203) сматра да је суфикс -ча хипокористични и претежно регионални (Коча, Јовча), а њиме се завршава и више топонима (Борча, Жича), али су оне углавном немотивисане (Стевановић 1964: 560). Употреба овог суфикса у творби атрибутивних именица указује на ширење његовог семантичко-деривационог потенцијала, нарочито у говорима призренско-тимочке дијалекатске области (ћop-ча, ћonча, иир-ча 'лакомац, грамжљивац', иљиn-ча 'неспретњак' [РНГЦР]). Суфиксу -ша се приписују две битне функције: хипокористичка с именичким основама (сеша, диша), и веома ретко агентивна у споју с основама глагола (изеша/изјеша = изелица) (Клајн 2003: 209). Он се не може сматрати плодним у творби атрибутивних именица, чак ни у народним говорима (глав-ша [ТДР]).

У македонским дериватим првога степена налазе се суфикси -e, -yч, -yu, којима се изражава субјективни став према именованом ентитету. Суфикс -e има деминутивно-хипокористичку функцију (Конески 1982: 290), а С. Велева наводи да његова продуктивност опада (2006: 156). У македонској дериватолошкој литератури нису потврђени суфикси -уч и -уш, што говори о њиховој архаичности, непродуктивности или о употреби у народним говорима. ${ }^{8}$

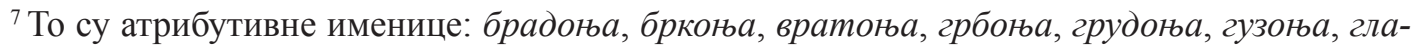
воња, зубоњ а, косоњ а, носоњ а, пупоњ а, трбоњ а, увоњ а, ухоњ а, ушоюа (Штасни 2013: 154).

${ }^{8}$ У српском језику се суфикс -уш не јавља ни у једној познатој речи (Клајн 2003: 198). Скок наводи да је суфикс -уш/-уша необично раширен у румунском нарочито у деминутивној функцији. Ту није словенског порекла, него илиро-трачког, а затим додаје да је можда и јуж-
} 
У основи другостепених деривата налазе се пејоративи/аугментативи: главура (главур-ан, главур-ача) или главурда (главурд-ан). Суфикс-ан се углавном додаје именичким основама, што је уочено и у словеначком (glav-an), и изузетно је плодан у комбинацији с основом соматизма, нарочито у западнијим говорима источнохерцеговачког дијалекта (мозг-ан, ћуб-ан, уш-ан, ииј-ан [РГГ]), али и у косовско-ресавском (зуб-ан [РК-МД]). Како наводи Клајн (2003: 389), изведенице су претежно афективне, с негативном конотацијом.

Суфикс -ача је полифункционалан и у споју с именичком основом нема одређено значење (Клајн 2003: 65). ${ }^{9}$ Међутим, у дијалектима у споју с основом соматизма веома често гради именице женског рода с пејоративним обележјем (брк-ача [РГГ, РГЗ], ръ-ача 'она која има широке ноздрве' [РГЈК], ок-ача, крст-ача, прс-ача, сис-ача [РГЗ], трбуљача [РК]).

Мотивне речи главура и главурда мотивисале су творбу атрибутивних именица, којима је у основи примарног значења синегдоха, и у које се преноси пејоративно обележје мотиватора. Секундарно значење деривата главурдан 'тврдоглав, задрт човек' настало је пак више под утицајем метафоре по асоцијативном моделу конкретно (физичко својство ентитета) $\rightarrow$ апстрактно (карактерна особина) (Штасни 2013: 118).

У другостепене деривате спадају и лексеме глават-ило и главољ-ииа. Први је с основом квалитативног придева глават, чији се семантички садржај такође заснива на компонентама изгледа и величине главе, други је деминутив од првостепеног деривата главоња. Употреба суфикса -ило у споју с придевском основом у творби атрибутивних именица није забележена у стандарду (Стевановић 1964; Клајн 2003; Šipka 2003), а пример забележен у говору Јасенова (југоисточни Банат) сведен је на хапакс, док се деривати с именичком основом и атрибутивним значењем могу срести у неким народним говорима (брғ-ило, кик-ило, рғ-ило [РГГ]). У творби персоналних атрибутивних именица суфикс -ица остварује своју уобичајену деминутивну функцију.

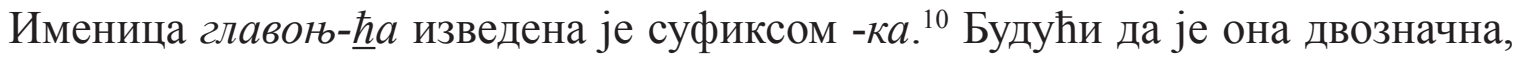
у примарном значењу деривата суфикс -ка дејствује као терминолошки, а у секундарном, које је настало под утицајем метафоричне асоцијације, реализује своју деминутивну функцију и атрибутивно својство. У македонском је ређе образовање другостепених деривата, као у примеру главуш-ија са суфиксом -ија турског порекла.

нословенски суфикс, као у неким изведеницама, где је могло доћи до укрштања словенског и илиро-трачког суфикса (Skok 1973: 550).

${ }^{9}$ На људско биће односи се само мушкарача, а са придевском основом то су углавном погрдни називи за жене (глупача, лудача, блесача) (Клајн 2003: 66).

${ }^{10}$ Суфикс -ка се јавља у тимочко-лужничким говорима у облику - $а$ након $j, љ$, , 
Сасвим је непродуктивно сложеничко именовање човека на основу својства 'велика глава', као у примерима бронз-о-глав-иле/бронs-о-глав-иле или глав-о-топ-ø $\rightarrow$ онај који има велику главу као бронзин/бронsин односно mon. У македонском језику нисмо забележили примере овог типа.

\section{Табела 1. Именовање човека према величини главе}

\begin{tabular}{|c|c|}
\hline $\begin{array}{l}\text { Првостепени } \\
\text { деривати у сј. }\end{array}$ & Дефиниција и извори \\
\hline глав-аш & $\begin{array}{l}\text { главоња (РМС); реч за ниподаштавање, алузија се чини на } \\
\text { велику, а празну главу (РК-МД) }\end{array}$ \\
\hline глав-оња & човек велике главе (РМС, РСГВ, РГЗ, РГЈК, РК) \\
\hline глав-ча & $\begin{array}{l}\text { глават човек (РГЈС), онај који има велику главу, главоња, } \\
\text { уп. главша (ТДР) }\end{array}$ \\
\hline глав-ша & в. главча (ТДР) \\
\hline $\begin{array}{l}\text { Првостепени } \\
\text { деривати у мј. }\end{array}$ & Дефиниција и извори \\
\hline глав-е & раз. главоња, главаш, в. главуш (МJ) \\
\hline глав-уч & $\begin{array}{l}\text { 1. човек со голема глава (РМЈ; ТРМЈ) 2. богат или влијателен } \\
\text { човек; буџа (РМJ); 3. човек на висока позиција, функционер, } \\
\text { директор (ТРМЈ) }\end{array}$ \\
\hline глав-уш & човек со голема глава (ТРМЈ) \\
\hline $\begin{array}{l}\text { Другостепени } \\
\text { деривати у сј. }\end{array}$ & Дефиниција и извори \\
\hline главур-ан & $\begin{array}{l}\text { особа велике главе, тврдоглава особа, не много паметна } \\
\text { особа (РТГ); дечачић велике главе (РК, ТДР) }\end{array}$ \\
\hline главур-ача & девојчица велике главе (РК) \\
\hline главурд-ан & главоња (РМС); особа са великом главом (ДРСК, ТДР) \\
\hline главоњ-ица & $\begin{array}{l}\text { дем. од главоња (РМС, РМСРК); мушка особа велике главе, } \\
\text { а малог тијела (РГЗ) }\end{array}$ \\
\hline 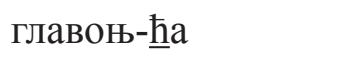 & 1. цвет конопље пун семена. 2. дем. од главоња (о деци) \\
\hline глават-ило & главоња (Банат - Јасеново) (РСГВ) \\
\hline
\end{tabular}




\begin{tabular}{|c|c|}
\hline $\begin{array}{l}\text { Другостепени } \\
\text { деривати у сј. }\end{array}$ & Дефиниција и извори \\
\hline главуш-ија & $\begin{array}{l}\text { човек со голема глава, глават човек (РМНП); главешина } \\
\text { (PMJ1) }\end{array}$ \\
\hline Сложенице у сј. & Дефиниција и извори \\
\hline $\begin{array}{l}\text { бронз-о-глав-иле/ } \\
\text { бронь-о-глав-иле }\end{array}$ & $\begin{array}{l}\text { мушка особа велике, чворновате главе; тупоглава мушка } \\
\text { особа }^{11} \text { (РГЗ) }\end{array}$ \\
\hline глав-о-топ- ${ }^{12}$ & главоња (РТГ2) \\
\hline
\end{tabular}

Наведени примери донекле се могу сматрати варијантним формама јер у њиховој деривацији учествује значајан број суфикса - у српском: $-a н,-a ч$, -оњ $a,-a u$, а у македонском -e, -yч, -yu, при чему се остварује иста концептуална вредност 'човек велике главе'. У основи другостепених деривата придев се као мотивна реч јавља сасвим спорадично, док главну мотивну финкцију имају аугментативна образовања. Иако ови деривати имају сличну семантичку структуру, разлике се испољавају у њиховој стилској обележености. У лексикографским интерпретацијама обично је примарно значење обележено као пејоративно, а погрдним или ироничним се сматрају остале семантичке реализације. Ове атрибутивне именице имају фигуративну употребу у неформалној комуникацији, што многим дијалекатским речницима није увек маркирано.

2.1.2. Атрибутивне именице мотивисане компонентом 'издлед/облик главе'. Компонента значења имплицитно садржана у појмовној вредности лексеме глава која носи информацију о изгледу мотивног појма не искључује компоненту његове величине. Наиме, оне су семантички удружене јер изглед подразумева и величину именованог ентитета. Ми их разврставамо у посебне групе будући да у деривационом погледу оне испољавају разлике. Када је реч о дериватима мотивисаним компонентом изгледа, у функцији мотивне речи налазе се квалитативни придеви настали сложено-суфиксалном творбом с компонентом глав- на другом сложеничком месту. Прва компонета има функцију детерминатора и квалификатора појма глава. То су најчешће придеви го, дебео, крив, рић, сед, ситан, а остале врсте речи се јављају по изузетку: именица бућ, глагол вити, вијем или број два. Мотивни придев у деривирану атрибутивну именицу преноси целокупан семантички садржај, и удружен суфиксима -( $a) u$

${ }^{11}$ Први сложенички део мотивисан је лексемом бронзин/бронsин 'емајлирани суд за кување, проширен на средини, ужи при дну и врху', односно његовим изгледом и величином.

${ }^{12}$ Атрибутивна именица главотоп може се онимизирати, при чему од апелатива постаје надимак Главотоп (РГЈК). 
и -иле (именице мушког рода), -ка (именице женског рода) или -че (именице средњег рода) гради номинациону јединицу атрибутивног својства.

Суфикс - $(a) u$ је веома продуктиван, нарочито с именичким и придевским основама. Има опште релационо значење, које се код именичких основа испољава у виду било какве везе с појмом у основи, код придевских значи носиоца особине означене придевом (Клајн 2003: 51). Као конкурентни формант суфиксу -( $а)$, , јавља се суфикс -иле, нарочито у говору Загарача, где је он веома продуктиван у комбинацији са основама соматизама (бандоглав-иле, жутобркиле, кривоврат-иле, кривогуз-иле, кривоног-иле, кривоуст-иле, псоглав-иле, тупоглав-иле, шкрбозуб-иле [РГЗ]). И суфикс -ка спада међу најважније моционе суфиксе, ${ }^{13}$ а суфикс -че је продуктиван деминутивни суфикс, типичан за јужнословенске језике (Клајн 2003: 203), а нарочито у приренско-тимочкој дијалекатској области и македонском језику.

Овим дериватима одговарају различите парафразе: а) онај који има $\mathrm{X}$ главу (X је мотивни придев), б) онај који Х-ује главом (X је мотивни глагол), в) онај који има $\mathrm{X}$ на глави (X је мотивна именица) или г) онај који има $\mathrm{X}$ главе (X је мотивни број). У перифрастичким моделима именица глава има функцију објекта (модел а и г), инструмента (модел б), локализатора (модел в). Ове атрибутивне именице су једнозначне, а само по изузетку остварују експресивно зачење (гологлавач 'сиромах'). Хипокористичко значење условљено је денотатом (гологлавче), а пејоративност изгледом односно положајем главе у односу на тело (кривоглавиле) или начином чешљања - глатко се чешљати као да се мазиш по глави (мазноглавка).

Табела 2. Именовање човека према изгледу/облику главе

\begin{tabular}{|l|l|}
\hline \multicolumn{1}{|c|}{ Деривати у сј. } & \multicolumn{1}{c|}{ Дефиниција и извори } \\
\hline бућоглав-ацц & бућоглав човек, са ћубом на глави (РМС) ${ }^{2}$ \\
\hline бућоглав-ка & женска особа бујне, разбарушене косе ${ }^{15}$ (РГЈК, РГЈС) \\
\hline вијоглав-ка & кривовратка (жена крива врата) (РНГЦР) \\
\hline
\end{tabular}

13 Теоријско тумачење моционих односа у деривацији може бити засновано на схватању о доминацији именице мушког рода у односу на мовирани фемининум (Ћорић 1981). Ми ћемо, међутим, именице мушког и женског рода овога типа сматрати именицама у моционом односу. Термин моциони однос употребљава се за „творбено-семантички однос између именица насталих од истог мотивног придева, а које се разликују само по роду” (Драгићевић 2001: 29).

${ }^{14}$ У РМС придев бућоглав има секундарно значење 'који има велику главу попут буће или бундеве', са потврдом из Шеное, али бућа у том значењу није забележена (бућ = ћуба и бућа= бундева не припадају истом деривационом гнезду) (СДР 2003: 105).

${ }^{15}$ Са компонентом бућ у значењу 'бујна разбарушена коса'. 


\begin{tabular}{|c|c|}
\hline гологлав-ац & онај који је голе главе; експр. сиромах (РMC) $)^{16}$ \\
\hline гологлав-ка & $\begin{array}{l}\text { женска особа која не повезује главу марамом, која је без } \\
\text { мараме на глави (РГЈК) }\end{array}$ \\
\hline гологлав-че & дете с ретком косом (РГЈК) \\
\hline двоглав-ацц & онај који има две главе, који је двоглав (РМС) \\
\hline дебелоглав-ацц & онај који има дебелу главу (РМС) $)^{17}$ \\
\hline кривоглав-иле & човјек чија је глава нагнута на једну страну (РГЗ) \\
\hline мазноглав-ка & глатко очешљана и дотерана жена (РГЈС) \\
\hline риђоглав-ац & риђокос човек (РМС) $)^{18}$ \\
\hline седоглав-ацц & седоглав човек (РМС) \\
\hline ситноглав-ац & онај који је ситноглав (РМС) \\
\hline
\end{tabular}

У деривацији атрибутивних именица с компонентом 'изглед главе' мотивација сложеним придевом представља системску појаву, а у њиховој творби поред суфикса -(a)u, као најпродуктивнијег, јављају се и суфикси -иле, -ка, -че. Дистрибуција неких од суфикса (-иле, -че) територијално је условљена. И ови деривати могу имати негативну експреспресивност, али су оне углавном стилски немаркиране, што је условљено семантичким садржајем мотивног придева. У македонским изворима нису посведочени примери овог творбеног типа.

\section{3. КВАЛИФИКАЦИЈА ЧОВЕКА ПРЕМА УНУТРАШЊИМ СВОЈСТВИМА}

3.1. Деривати мотивисани соматизмом глава именују човека и на основу његових интелектуалних и карактерних особина. У том погледу доминантну мотивну функцију има компонента значења која се односи на функцију

${ }^{16}$ Придев гологлав има полисемантичну структуру 1. 'који је непокривене главе, који је без капе или шешира, без мараме'; 2. експр. а. 'оголео, огољен, који је без лишћа (о биљци)'; б. 'који је без звона (о цркви)'. Његове секундарне реализације настале су под утицајем метафоричне асоцијације засноване на изгледу именованог ентитета.

${ }^{17}$ Мотивни придев дебелоглав има два значења, примарно'који има дебелу главу' и секундарно 'будаласт'.

${ }^{18}$ Сложенице с називом боје на првом месту чешће су у функцији мотиватора зоолошких термина: ирвеноглаваи а. 'инсект црвене главе Erythrocephalus'; б. 'чешљугар; птица црвене главе уопште', ирвеноглавка 'птица црвене главе', црноглаваи 1. 'црноглавка (1)'; 2. терм. бот. а. 'кукурек'; б. 'горешник', црноглавица 1. 'црноглавка (1)'; 2. терм. вет. 'болест кокошака и ћурака од које им поцрни глава', црноглавка 'птица црне главе Sylvia atricapilla' или ботаничког термина златоглавка. 
главе. Ове су атрибутивне именице, такође, веома продуктивне у српском и македонском језику.

3.1.1. Именовање човека према интелектуалном својству. Атрибутивне именице којима се означава човек према интелектуалним способностима првенствено су деривати првога степена, с основом соматизма глава (глав- $а н$, глав-ша) или с основом сложеног квалификативног придева (дебелоглав-аи) дебелоглав-ец, празноглав-ац̧/празноглав-ец). Квалификација човека према унутрашњим својствима је, по правилу, негативна, што се очитује и на плану семантичке деривације. Наиме, код вишезначних јединица ова значења јављају се као секундарне реализације, по принципу: велика, а празна глава (главоюа [РСГВ], главаш [РК-МД], главиа [РСК, ТДР] 'глуп човек'). Значења наведених деривата настала су под утицајем метафоре у процесу семантичке деривације. Овој групи припада и лексема главина. На основу објашњења датом у извору (РНГЦР) могло би се закључити да је значење 'глупак' (од главина 'главчина у точку'), секундарна реализација с фигуративним значењем лексеме главина насталом метафоричном асоцијацијом, која је заснована на преносу номинације с предмета на својство човека (неживо $\rightarrow$ живо; предмет $\rightarrow$ човек).

\begin{tabular}{|l|l|}
\hline \multicolumn{2}{|c|}{ Семантички деривати у сј. } \\
\hline глав-аш & $\begin{array}{l}\text { 'реч за ниподаштавање, алузија се чини на велику, а празну главу' } \\
\text { (РК-МД) }\end{array}$ \\
\hline глав-оња & 4. 'глуп човек' (РСГВ) \\
\hline глав-ша & 2. 'глупак' (РСК, ТДР) \\
\hline глав-ина & 2. 'в. глупак' (РНГЦР) \\
\hline
\end{tabular}

Творбеном деривацијом настају деривати првога степена, и то само спорадично у примеру глав-ан, што је и очекивано будући да је за исказивање атрибутивног концепта у оквиру овог појмовног домена (интелектуална својства) неопходна јединица којом се изражава таква квалификација. Стога је продуктивнија творба именица овога типа с основом сложеног квалитативног придева, који у дериват преноси неко од својих секундарних значења: дебелоглав-ец, празноглав-ац/празноглав-ец и празноглав-ица, празноглав-иле, тупоглав-ац/тапоглав-ец и тупоглав-ица, тупоглав-ка, шупљоглав-аци/иупљив-ец, шупљоглав-иле. Мотивни придеви настали су по моделу По + о + Ио + -ø. ${ }^{20}$

\footnotetext{
${ }^{19}$ Ово значење се реализује у косовско-метохијским дијалектима, али не и у стандарду.

${ }^{20} \mathrm{У}$ македонском само у једном случају употребљена је основа простог придева - шупливец пеј. 'празноглав човек' (ТРМЈ).
} 
Супстантивизацијом су настали облици празноглав и празноглава. У основи атрибутивних именица вртоглав-ка и вртоглав-цтина налазе се квалитативни придеви настали по моделу Го + о + Ио + суфикс. Суфикс -штина у дериват уноси пејоративно значење. У македонском језику пак лексемом вртоглав-еи именује се човек према карактерном својству вртовереи и вртоверка 'непостојано лице; превртливец' (ТРМЈ).

Забележени су примери с глаголским основама: врт-о-глаја $($ Го + о + И) и свр-глаја $(\text { Го }+ \text { И })^{21}$, при чему је именица на другом сложеничком месту у измењеном фонетском лику. Један мотивни придев (без-глав-ø) настао префиксално-суфиксалном творбом и у основи је атрибутивне именице безглав-ац.

Табела 3. Именовање човека према интелектуалном својству

\begin{tabular}{|l|l|}
\hline \multicolumn{1}{|c|}{ Деривати у сј. } & \multicolumn{1}{|c|}{ Дефиниција и извори } \\
\hline глав-ан & $\begin{array}{l}\text { 'реч за ниподаштавање, алузија се чини на велику и празну } \\
\text { главу' (РСК) }\end{array}$ \\
\hline безглав-ац & 'онај који је безглав, односно збуњен, избезумљен' (РМС) \\
\hline вртоглав-ка & 'приглупа (ћакнута) женска особа' (РТГ2) \\
\hline вртоглав-штина & 'ћакнута и ментално ненормална особа' (ТДР) \\
\hline празноглав & $\begin{array}{l}\text { 'празноглавац' (РМС),22 'онај који је празне главе, који ништа } \\
\text { не зна, будалетина' (РГЗ) }\end{array}$ \\
\hline празноглава & $\begin{array}{l}\text { 'женска особа која ништа не зна, вијомозгаста женска особа' } \\
\text { (РГз) }\end{array}$ \\
\hline празноглав-ац & 'онај који је празне главе, човек умно ограничен' (РМС) ${ }^{23}$ \\
\hline празноглав-ица & 'празноглава особа' (РМС) \\
\hline празноглав-иле & 'празноглава мушка особа' (РГЗ) \\
\hline тупоглав-ацц & 'тупоглава мушка особа' (РМС); '24 'глупа мушка особа' (РГЗ) \\
\hline тупоглав-иле & 'приглупа мушка особа' (РГЗ) \\
\hline тупоглав-ица & 'тупоглава женска особа' (РМС) \\
\hline тупоглав-ка & 'тупоглавица' (РМС) \\
\hline
\end{tabular}

${ }^{21}$ На творбеном шаву најпре долази до удвајања финалног сугласника аористне основе (сврг-ох) и иницијалног г у именичкој основи, а затим до губљења једног од њих.

${ }^{22}$ Важи иста напомена као у фн. 7.

${ }^{23}$ Мотивни придев празноглав има значење 'који је празне главе, умно ограничен'.

${ }^{24}$ Мотивни придев тупоглав значи 'који је слабе памети, умно ограничен, празноглав, глуп'. 


\begin{tabular}{|l|l|}
\hline шупљоглав-ацц & $\begin{array}{l}\text { 'шупљоглав човек, празноглавац' (РМС); 'шупљоглав мушка- } \\
\text { рац онај који мало зна, ко је шупле главе' (РГГ), }{ }^{25} \text { 'непаметна } \\
\text { мушка особа, шупљоглав човјек' (РГЗ) }\end{array}$ \\
\hline шупљоглав-иле & 'шупљоглава, празноглава мушка особа' (РГЗ) \\
\hline врт-о-глаја & 'онај који је плитке памети, мало ћакнут' (РГГ) \\
\hline свр-глаја & 'онај који изгледа као изгубљен и свргнут' (РГГ) \\
\hline $\begin{array}{c}\text { Првостепени } \\
\text { деривати у мј. }\end{array}$ & \multicolumn{1}{|c|}{ Дефиниција и извори } \\
\hline дебелоглав-ец & $\begin{array}{l}\text { 'тој што е дебелоглав - што тешко сфаќа, прифаќа, што тешко } \\
\text { разбира што му се зборува' (ТРМЈ) }\end{array}$ \\
\hline празноглав-ец & 'тој што е глупав, умствено ограничен, празноглав човек' (ТРМЈ) \\
\hline тапоглав-ец & пеј. 'тапоглаво лице' (ТРМЈ) \\
\hline
\end{tabular}

Атрибутивним именицама из ове групе именује се човек према умањеним интелектуалним способностима, дакле, с негативном квалификацијом, док је позитивна потпуно блокирана. Значење атрибутивних именица 'глуп човек' остварује се семантичком и творбеном деривацијом. У њиховој основи налазе се квалитативни придеви који у дериват углавном преносе неко од својих секундарних метафоричних значења (туn, празан, шупаљ). Именице с мушком особом као денотатом изведене су суфиксом -(a)u/-ец, а његов конкурент у неким српским народним говорима је суфикс -иле (РГЗ). Моциони облици су са суфиксом -ка или -ица, који се јавља и код двородних именица. Све атрибутивне именице из ове групе не подлежу ширењу семантичке структуре. У македонском суфикс -ец има тенденцију да поприми статус категоријалног суфикса у творби атрибутивних именица (Велева 2006: 149).

3.1.2. Именовање човека према карактеру. У овој лексичкој скупини такође разликујемо деривате настале семантичком и оне настале творбеном деривацијом. Поред примера у којима је атрибутивно значење овога типа настало под утицајем метафоре, забележен је и пример у којем је у основи синегдоха с преносом номинације од примарног аугментативног и пејоративног значења на човека с одређеном карактерном особином и негативном квалификацијом.

${ }^{25}$ Мотивни придев шупљоглав значи 'који тешко схвата, ограничен, тупав'. 


\begin{tabular}{|l|l|}
\hline \multicolumn{2}{|c|}{ Семантички деривати у сј. } \\
\hline глав-оња & 4. 'тврдоглав, самовољан, непокоран човек' (РГЈК) \\
\hline главурд-ан & $\begin{array}{l}\text { 2. 'тврдоглав, задрт човек' (РМС); 2. 'уображена особа' } \\
\text { (ДРСК, ТДР) }\end{array}$ \\
\hline главур-ина & $\begin{array}{l}\text { 1. аугм. и пеј. од глава 'велика глава'; 2. 'уображена особа, } \\
\text { усијана глава' (ТДР) }\end{array}$ \\
\hline
\end{tabular}

Атрибутивне именице којима се човек именује према свом карактеру такође су најчешће мотивисане квалитативним сложеним придевом. Само је атрибутивна именица глав-нина с основом соматизма глава (Клајн 2003: 98). ${ }^{26}$ Међу мотивним придевима налазимо различите творбене моделе. Концептуално су сродни придеви творбеног типа По + о + Ио + -ø (тврдоглав) и Зо + о + Ио + -ø (самоглав, својеглав). У њихове деривате се преноси цео семантички садржај, као и при номинацији човека према интелектуалним способностима. Највише атрибутивних именица мотивисано је придевом тврдоглав: тврдоглав-и/тврдоглав-еи, тврдоглав-ко и моционо образовање тврдоглав-ка, тврдоглав-иле, тврдоглав-оња (за мушки род), и двородне именице тврдоглав-ииа и тврдоглав-итина. Ови деривати су претежно једнозначни. Секундарно терминологизовано значење из области зоологије има лексема тврдоглавач 'инсекат врсте тврдокрилаца, корњаша Anobiidae', и атрибутивна именица самоглаваи 1. 'својеглав, тврдоглав човек, тврдоглавац'; 2. 'човек нежења, самац', а у македонском само са другим значењем, које се може сматрати архаичним (самоглав-еи/самоглав-ица, самоглав-ник/самоглавница заст. 'самец'). Основно значење мотивног придева самоглав индуковало је примарну реализацију деривата, а семантички садржај његове секундарне реализације преноси се у секундарно значење атрибутивне именице.

Квалитативни придев пасоглав с творбеном структуром Ио + о + Ио +-ø, подлеже супстантивизацији градећи атрибутивну именицу пасоглав, у коју се преноси удружени семантички садржај обеју саставница. Значење ове сложенице би се могло изразити као 'човек псеће нарави', где прва компонента има детерминативну и квалификативну функцију, а друга се семантички удаљава од значења мотивне речи попримајући апстрактно значење довођењем у везу мотивне лексеме глава с апстрактумом нарав.

Сложено-суфиксалном творбом настао је квалитативни придев с првим сложеничким делом чија је мотивација непрозирна (ЕРСЈ) бандоглав 'тврдо-

${ }^{26}$ Овде би се могла претпоставити и придевска мотивација главн-ина са парафразом 'онај који увек сматра да је главни'. 
глав, настран'27. Овај ће придев мотивисати деривацију атрибутивних именица бандоглавац 'бандоглавко, бандоглав човек' и фемининум бандоглавица .

Сложеницама насталим по моделу Ио + о + Го + -ø (главос́ек 'храбар, силовит човек' (РК); 'онај који је сјекао главе у рату, јунак (РГЗ)'; 28 главосек и главорез 1. 'џелат'; 2. пеј. 'касап, крвник' (ТРМJ)'; главождер 1. 'убица (вишеструки)'; 2. 'човјек који је на високом положају' (РГЗ) одговара парафраза 'онај који Х главу', где је Х глагол у презенту (онај који сече, реже, ждере), а лексема глава има функцију објекта.

Табела 4. Именовање човека према карактеру

\begin{tabular}{|c|c|}
\hline Деривати у сј. & Дефиниција и извори \\
\hline глав-нина & 'тврдоглава, својеглава особа, особењак' (РСК) \\
\hline бандоглав-ㅁц & $\begin{array}{l}\text { 'бандоглавко, бандоглав човек' (РМС); }{ }^{29} \text { 'бандоглав човјек, } \\
\text { својеглавац, тврдоглавац, намћор' (РГЗ) }\end{array}$ \\
\hline бандоглав-иле & 'бандоглава мушка особа' (РГЗ) \\
\hline бандоглав-ица & 'бандоглава женска особа' (РМС) \\
\hline бандоглав-оња & ’бандоглавко’ (РГЈК) \\
\hline бандоглав -ка & 'тврдоглава, својеглава, самовољан женска особа' (РГЈК) \\
\hline бандоглав-ко & $\begin{array}{l}\text { 'тврдоглава, својеглава, самовољана мушка особа; исп. } \\
\text { бандоглавоња' (РГЈК) }\end{array}$ \\
\hline пасоглав ${ }^{30}$ & ’пасоглавац' (РМС) \\
\hline пасоглав-ац & 'зао, опак човек' (РМС) \\
\hline псоглав-иле & $\begin{array}{l}\text { 'особа лошег понашања, љута мушка особа, бескарактерна } \\
\text { мушка особа' (ГЗ) }\end{array}$ \\
\hline пасоглав-ица & 'зла, опака жена' (РМС) \\
\hline
\end{tabular}

${ }^{27} \mathrm{Ca}$-глав као другим делом сложенице у РМС су забележени и: злоглав покр. а. 'тврдоглав, јогунаст'; б. 'који је луде главе, луд'; климоглав шаљ. 'поздрав поклоном главе', а одатле и климоглавач ков.; плосноглав = пљосноглав 'онај који је плосне главе', плосноглаваи зоол. = пљосноглаваи 'врста великог пужа без љуштуре који има плосну главу Tethys'; смртоглав индив. 'необично јак, силан'; суровоглав необ. 'упоран, тврд, суров'; чичоглав 'који је чупаве, кудраве косе (као да је пуна чичака)' (СДР 2003: 105).

${ }^{28}$ Апелатив главосек подлеже онимизацији и постаје део онима Свети Јован Главосек, са парафразом 'онај коме је одсечена глава', при чему агенс, као у примеру главосек 'онај који сече главе' у овом случају постаје пацијенс.

${ }^{29}$ Квалитативни придев бандоглав има значење 'тврдоглав, настран'.

${ }^{30}$ Именица настала конверзијом односно супстантивизацијом придева пасоглав 'зао, опак' 


\begin{tabular}{|c|c|}
\hline самоглав-ац & $\begin{array}{l}\text { 1. 'својеглав, тврдоглав човек, тврдоглавац'; 2. 'човек не- } \\
\text { жења, самац' (РМС) }\end{array}$ \\
\hline самоглав-ник & $\begin{array}{l}\text { 'онај који је својеглав, својевољан, тврдоглав' (РГЈК); 'твр- } \\
\text { доглавац, самовољник' (РНГЦР) }\end{array}$ \\
\hline самоглав-ница & $\begin{array}{l}\text { 'она која је својеглава, својевољна, тврдоглава' (РГЈК); } \\
\text { 'тврдоглавица' (РНГЦР) }\end{array}$ \\
\hline својеглав-ацц & 'својеглав, тврдоглав човек' (РМС) ${ }^{32}$ \\
\hline својеглав-ица & 'својеглава, тврдоглава жена' (РМС) \\
\hline тврдоглав-미 & $\begin{array}{l}\text { 1. 'тврдоглав човек'; 2. терм. зоол. 'инсекат врсте тврдокри- } \\
\text { лаца, корњаша Anobiidae ' (РMC) })^{33}\end{array}$ \\
\hline тврдоглав-ица & 'тврдоглава особа; тврдоглава жена' (РМС, РДГ) \\
\hline тврдоглав-ка & 'она која је тврдоглава, својеглава, својевољна' (РМС, РГЈК) \\
\hline тврдоглав-ко & 'онај који је тврдоглав, својеглав, својевољан' (РМС, РГЈК) \\
\hline тврдоглав-иле & 'непослушан, који не одустаје од својих ставова' (РГЗ) \\
\hline тврдоглав-оња & 'тврдоглавко' (РГЈК) \\
\hline тврдоглав-штина & 'онај који је тврдоглав' (ТДР); 'тврдоглавац' (РНГЦР) \\
\hline чвороглав-иле & 'тврдоглава мушка особа' (РГЗ) \\
\hline Деривати у мј. & Дефиниција и извори \\
\hline вртоглав-ец & $\begin{array}{l}\text { вртоверец/вртоверка 'непостојано лице; превртливец' } \\
\text { (ТРМJ) }\end{array}$ \\
\hline дебелоглав-ец & дебелоглав човек 'тврдоглав или своеглав' (РМЈ) \\
\hline тврдоглав-ец & тврдоглав човек (ТРМЈ) \\
\hline $\begin{array}{l}\text { самоглав-ец/само- } \\
\text { глав-ица }\end{array}$ & заст. 'самец' (ТРМJ) \\
\hline $\begin{array}{l}\text { самоглав-ник/ само- } \\
\text { глав-ница }\end{array}$ & заст. 'самоглавец, самец' (ТРМЈ) \\
\hline
\end{tabular}

${ }^{31}$ Мотивни придев самоглав значи 1. 'својеглав, самовољан'; 2. 'који живи као самац'.

${ }^{32}$ Мотивни придев својеглав користи се у значењу 'тврдоглав, самовољан'.

${ }^{33}$ Мотивни придев тврдоглав има два значења 1. 'који упорно остаје при свом, који не уважава никакве разлоге и доказе сем својих, својеглав'; 2. 'непокоран, непослушан'. 


\begin{tabular}{|c|c|}
\hline Сложенице у сј. & Дефиниција и извори \\
\hline глав-о-с́ек-Ø ${ }^{34}$ & $\begin{array}{l}\text { 'храбар, силовит човек' (РК); 'онај који је сјекао главе у } \\
\text { рату, јунак' (РГЗ) }\end{array}$ \\
\hline глав-о-ждер-ø & $\begin{array}{l}\text { 1. 'убица (вишеструки)' (РГЗ); 2. 'човјек који је на високом } \\
\text { положају' (РГЗ) }\end{array}$ \\
\hline глав-о-ед-ник & $\begin{array}{l}\text { 'онај који другоме ради о глави, који припрема нечију про- } \\
\text { паст уп. главоизедник' (ТДР) }\end{array}$ \\
\hline глав-о-изед-ник & 'главоедник' \\
\hline Сложенице у мј. & Дефиниција и извори \\
\hline глав-о-сек-ø & 1. 'џелат'; 2. пеј. 'касап, крвник' (ТРМЈ) \\
\hline глав-о-рез-ø & 1. 'џелат'; 2. пеј. 'касап, крвник’ (ТРМЈ) \\
\hline
\end{tabular}

Овим атрибутивним именицама означен је човек према непожељној карактерној особини (тврдоглавост, својеглавост, па и зао, опак човек). Потпуно позитивна конотација изостаје, па и када се дериватом означава храбар и силовит човек (главосек [РК]), његова употреба је негативно мотивисана (подругљиво).

Значење ових јединица остварује се семантичком и творбеном деривацијом - извођењем и ређе слагањем. У творбеним дериватима мотивну функцију имају квалитативни придеви с компонентом дебео, тврд, свој, при чему се у дериват преноси њихово секундарно значење углавном настало посредством метафоре. У творби деривата мушког рода најпродуктивнији је суфикс -(a)u/ -(e)u, а његов конкурент и у овој групи атрибутивних именица у неким српским народним говорима је суфикс -иле (РГЗ). Следе мање продуктивни суфикси територијално условљени: -ко (РМС, РГЈК), -ник (РГЈК, РНГЦР), -оља (РГЈК), -штина (ТДР, РНГЦР) и нулти суфикс у сложено-суфиксираним дериватима (РК, РГЗ). Именице женског рода изведене су уобичајеним моционим суфиксима -ка, -ица и -нициа. Поједине атрибутивне именице с овом концептуалном вредношћу имају способност семантичког варирања, са секундарним атрибутивним (самоглаваи 'човек нежења, самац', главождер 'човјек који је на високом положају') или терминологизованим значењем (тврдоглаваи 'инсекат врсте тврдокрилаца, корњаша Anobiidae').

${ }^{34}$ Атрибутивна именица главосек мотивисала је деривацију именице с колективним значењем главосек-овићи, с помало пејоративном употребом и значењем 'потомци главосјеча, потомци јунака' (РГЗ). 
Ове атрибутивне именице имају изражено експресивно својство, без обзира на то да ли је оно у речницима кодирано, маркирајући и самим тим истичући код човека лош и непријатан карактер.

\section{4. ЗАКЉУЧАК}

Деривација атрибутивних именица с основом соматизма глава представља значајан процес у систему српског и македонског језика. Захваљујући богатом семантичком садржају мотивне речи, у њеном деривационом гнезду заступљени су деривати различите семантике: речи субјективне оцене (дем. главица/ллавица, ауг. главурда/главиште), именице с предметним значењем (главчива/главина), агентивне именице (поглавар/главатар), терминологизоване јединице (зоол. ирвенперка/ирвеноперка 'врста рибе'). Ови деривати су индуковани различитим семантичким компонентама садржаним у примарном значењу лексеме глава. Када је реч о атрибутивним именицама, оне су углавном мотивисане компонентама које су имплицитно садржане у појмовној вредности мотивне речи - величина, облик, функција главе.

Као и остале, и атрибутивне именице имају општу номинациону и референцијалну функцију, с тим што оне изражавају и субјективни однос говорника према именованом референту, и зато су у речницима посебно обележене као аугментативи, пејоративи, вулгаризми, речи из домена разговорног језика и сл. Соматизми имају важну улогу у деривацији ове именичке категорије, а посебно лексема глава, као централни соматски појам, чијим се дериватима именује и квалификује човек према спољашњим особинама - величини и изгледу односно облику главе и према унутрашњим - интелектуалним и карактерним својствима, и то углавном на основу семе функције.

Са деривационог становишта атрибутивне именице индуковане компонентом величине главе у оба посматрана језика и њиховим дијалектима настају углавном суфиксацијом, а по изузетку слагањем. У значење првостепених деривата преноси се целокупан семантички садржај примарне реализације мотивне речи с придруженим квалификатором 'велики' (нпр. глав-оњ $а$ 'онај који има велику главу', док се у основи деривата другог степена налазе аугментативи/пејоративи (нпр. главурдан 'главоња'). У деривацији ових именица учествује већи врој суфикса с примарном агентивном или атрибутивном функцијом (-оњ $a,-a m /-e)$, али и они који су фреквентнији у народним говорима $(-a \mu,-ч a,-ш a)$ или који су подлегли архаизацији $(-y u,-y w)$. Територијална условљеност употребе одређеног суфикса изражена је и у другостепеним дериватима (-ило/-иле). Деривати којима се остварује концептуална вредност 'онај који има велику главу' могу се сматрати варијантним облицима, а међу суфиксима постоји делимична конкурентност услед утицаја територијалног, 
али и прагматичког фактора. Наиме, иако су све ове именице с експресивним обележјем, поједини суфикси у њихово значење уносе виши или нижи степен негативне тоналности (нпр. -оњ $а$ који у дериват уноси пејоративно значење и -ан чији је дериват експресиван због семантичког садржаја основе).

Атрибутивне именице мотивисане компонентом 'изгледа/облика главе' специфичне су по томе што се у њиховој основи налази квалитативни сложени мотивни придев који у свом саставу поред компоненте глава садржи придев којима се квалификује глава (го, дебео, крив, рић, сед, ситан). У њиховој творби најпродуктивнији је суфикс -(a)u, а конкурентан му је суфикс -иле који се употребљава у народним говорима. У македонским изворима нисмо регистровали именице овога семантичко-деривационог типа. И атрибутивне именице којима се именује човек према интелектуалном својству и карактеру такође су углавном мотивисане квалитативним придевима у оба језика у чијој је деривацији доминантан суфикс - $(a) u /$-ец, али се чешће јављају и суфикси -ко, -ица, -иле, -ник. Остали творбени процеси, попут слагања и конверзије, представљају периферну појаву у деривацији именица овога семантичког типа.

С обзиром на то да је реч о персоналним атрибутивним именицама, творба моционих образовања представља системску појаву, иако сви моциони облици нису потврђени у консултованим изворима (тупоглавица и тупоглавка 'тупоглава женска особа'). Они се изводе суфиксима чија је моциона функција доминантна и при чему се успоставља конкурентни однос (-ица и -ка). Атрибутивно значење може бити условљено денотатом, при чему се остварује позитивна конотација (гологлавче 'дете с ретком косом') или су пак оне стилски немаркиране гологлавка 'женска особа која не повезује главу марамом, која је без мараме на глави', али када је денотат мушка особа дериват гологлавац поред значења 'онај који је голе главе' има и експресивну реализацију 'сиромах' .

Осим творбене, важна је и семантичка деривација која се остварује у оквиру семантичке структуре вишезначних деривата из категорије атрибутивних именица којима се именује човек према величини и облику главе. Секундарна значења која се односе на интелектуална односно карактерна својства човека мотивисана су асоцијативним моделом велика, а празна глава, односно тврда глава (главурдан 1. 'главоња; 2. 'тврдоглав, задрт човек'; дебелоглавеи 'тој што е дебелоглав, што тешко сфаќа, прифаќа, што тешко разбира што му се зборува'). У појединим случајевима секундарна значења су терминологизована (тврдоглавац 1. атриб. имен. 'тврдоглав човек'; 2. терм. зоол. 'инсекат врсте тврдокрилаца, корњаша Anobiidae'. Посведочен је, међутим, и семантички трансфер обрнутог смера, тј. да се атрибутивно значење остварује као секундарно под дејством синегдохе или асоцијације метафоричног типа (главусина 1. аугм. и пеј. од глава 'главурда'; 2. атриб. имен. 'главешина'; вијоглавка 1. терм. зоол. 'птица из реда пузачица'; 2. атриб. имен. 'вијоглава женска особа'. 
На плану експресивности ове атрибутивне именице углавном су с негативним обележјем, а она је индукована значењем које суфикс уноси у дериват (-ољ $a,-$-ил) или семантичким садржајем творбене основе (када је аугментатив у основи [главурдан], или придев у структури сложеног мотивног придева [шупьвоглаваи, тврдоглаваџ]).

\section{ИЗВОРИ}

СДР1 2003: Семантичко-деривациони речник, Свеска 1: Човек-делови тела, (Ред. Д. Гортан-Премк, В. Васић, Љ. Недељков), Нови Сад: Филозофски факултет.

PMC 1967-1976: Речник српскохрватскога књижевног језика, I-VI, Нови Сад - Загреб: Матица српска - Матица хрватска.

PCJ 2007: Речник српскога језика (Ур. М. Николић), Нови Сад: Матица српска.

Г-СР 2009: Александар Балаћ и Миодраг Стојановић, Грчко-сриски речник, Београд: Завод за уџбенике.

РГГ 2015: Милош Бојиновић, Рјечник гламочког говора, Српски дијалектолошки зборник, LXII. Београд: Институт за српски језик САНУ, $1-246$.

РГЈК 2005: Радмила Жугић, Речник говора јабланичког краја, Српски дијалектолошки зборник, LII. Београд: Институт за српски језик САНУ, 1-461.

PГJC 1998: Момчило Златановић, Речник говора јужне Србије (провинцијализми, дијалектизми, варваризми и др.), Врање: Учитељски факултет.

РГП 2004: Стево Далмација, Рјечник говора Поткозарја, Бања Лука: Глас српски - Графика.

РК 2013: Драгољуб Петровић, Ивана Ћелић и Јелена Капустина, Речник Куча, Српски дијалектолошки зборник, LX. Београд: Институт за српски језик САНУ, 1-461.

РК-МД 1932: Глигорије Глиша Елезовић, Речник косовско-метохијског дијалекта, Свеска прва, Српски дијалектолошки зборник, IV. Београд: Институт за српски језик САНУ.

РК-МД 1935: Глигорије Глиша Елезовић, Речник косовско-метохијског дијалекта, Свеска друга, Српски дијалектолошки зборник, VI. Београд: Институт за српски језик САНУ. 
PMJ 2005: Зозе Мургоски, Речник на македонскиот јазик, Скопје: Филолошки факултет „Блаже Конески”.

PМJ1 1961: Речник на македонскиот јазик со српскохрватски толкувања, (Ред. Б. Конески), Скопје: Институт за македонски јазик.

РМНП 1983: Речник на македонската народна поезија, Том 1 (А-Г), Скопје: Институт за македонски јазик „Крсте Мисирков”.

РСГВ 2000-2010: Речник српских говора Војводине, Свеске 1-10, Нови Сад: Матица српска, Одељење за књижевност и језик, Лексикографска издања, Књига III, Дијалекатски речници, Књига 2.

ТРМJ 2003-2014: Толковен речник на македонскиот јазик, (Ред. К. Конески), I-VI. Скопје: Институт за македонски јазик „Крсте Мисирков”.

ЛВ 1990: Рада Стијовић, Из лексике Васојевића, Српски дијалектолошки зборник, XXXVI. Београд: Институт за српски језик САНУ, 119-379.

РГЗ 1997: Драго Ћупић и Жељко Ћупић, Речник говора Загарача, Српски дијалектолошки зборник, XLIV. Београд: Институт за српски језик САНУ, 3-574.

РДГ 2002: Михаило Бојанић и Растислава Тривунац, Рјечник дубровачког говора, Српски дијалектолошки зборник, XLIX. Београд: Институт за српски језик САНУ, 1-458.

РНГЦР 1986: Миодраг Марковић, Речник народног говора Црне Реке, Српски дијалектолошки зборник, XXXII. Београд: Институт за српски језик САНУ, 243-500.

РСК 2004: Властимир Јовановић, Речник села Каменице код Ниша, Српски дијалектолошки зборник, LI. Београд: Институт за српски језик САНУ, 313-688.

ДРСК 2007: Властимир Јовановић, Додатак Речнику села Каменице код Ниша, Српски дијалектолошки зборник, LIV. Београд: Институт за српски језик САНУ, 403-520.

РТГ 1992: Јакша Динић, Речник тимочког говора, Српски дијалектолошки зборник, XXXVIII. Београд: Институт за српски језик САНУ, 379-586.

ТДР 2008: Јакша Динић, Тимочки дијалекатски речник, Монографије 4, Београд: Институт за српски језик САНУ.

PТГ2 2014: Љубиша Рајковић Кожељац, Речник тимочког говора, Неготин: Књижевно-издавачко друштво Лексика. 
$*$

SH-SS 1972: Janko Jurančič, Srbskohrvatsko-slovenski slovar, Ljubljana: Državna založba Slovenije.

\section{ЛИТЕРАТУРА}

Ајџановић 2007: Милан Ајџановић, Корелативне предикације именица типа nomina attributiva, Лингвистичке свеске, 6, 72-83.

Велева 2006: Славица Велева, Тенденции во зборообразувањето во македонскиот јазик, Скопје.

Вељковић Станковић 2016: Драгана Вељковић Станковић, Експресивност евалутивних деривата изведених суфиксима -оњ $a$ и -уља - аксиолошки приступ, Научни састанак слависта у Вукове дане, 45/1, 323-335.

Драгићевић 2001: Рајна Драгићевић, Придеви са значенем људских особина у савременом српском језику (Творбена и семантичка анализа), Библиотека Јужнословенског филолога, Нова серија, Књ. 18, Београд: Институт за српски језик САНУ.

Драгићевић 2007: Рајна Драгићевић, Лексикологија српског језика, Београд: Завод за уџбенике и наставна средства.

Клајн 2003: Иван Клајн, Творба речи у савременом српском језику, Други део - суфиксаиија и конверзија. Београд - Нови Сад: Завод за уџбенике и наставна средства - Институт за српски језик САНУ - Матица српска.

Конески 1982: Блаже Конески, Граматика на македонскиот литературен јазик: дел 1 и 2, II изд. Скопје: Култура.

Стевановић 1964: Михаило Стевановић, Савремени српскохрватски језик, Београд: Научно дело.

Ћорић 1981: Божо Ћорић, Именички суфикси с иницијалним ч, Кғьижевни језик, X/4, 15-18.

Штасни 2007: Гордана Штасни, Атрибутивне именице (nomina attributiva) у српском језику, Српски језик. Студије српске и словенске, 12/1-2, 469-483.

Штасни 2013: Гордана Штасни, Речи о човеку (Номиначија човека у српском језику), Нови Сад: Филозофски факултет. 

Штасни 2016: Гордана Штасни, Именице са ознаком подругљиво у Речнику српскохрватскога књижевног језика, Научни састанак слависта у Вукове дане, 45/1, 349-359.
Штрбац/Штасни 2017: Гордана Штрбац и Гордана Штасни, Соматизми и концептуализаџија стварности у српском језику, Нови Сад: Филозофски факултет.

$*$

Šipka 2003: Danko Šipka, Rečnik tvorbenih formanata, Beograd: Алма.

Skok 1973: Petar Skok, Etimologijski rječnik hrvatskoga ili srpskoga jezika, Zagreb: Jugoslavenska akademija znanosti i umjetnosti.

\section{ATTRIBUTIVE NOUNS MOTIVATED BY SOMATISM HEAD IN SERBIAN AND MACEDONIAN LANGUAGE AND THEIR DIALECTS}

\section{Summary}

In this paper we analyzed from semantic and derivative aspect attributive nouns motivated by the lexeme head in the Serbian and Macedonian language and their dialects. These derivatives occupy a significant place in the lexical system of the Serbian and Macedonian language, and they are mostly motivated by components that are implicitly contained in the conceptual value of the motive word - size, shape, function of the head. These derivatives are used for nomination and qualification of a person according to the external characteristics - size and appearance that is, the shape of the head, and according to the inner characteristics - intellectual and character traits, mainly based on the semantic component of function.

From the aspect of derivation, attributive nouns induced by the head size semantic component in both of the observed languages and their dialects are formed mainly by suffixation, and rarely by composition. These attributive nouns can be considered as variant forms, and among suffixes there is partial competitiveness due to the influence of the territorial as well as the pragmatic factors. Attributive nouns motivated by the semantic component 'look/shape of a head' are specific because in their bases there is a qualitative compound motive adjective. That adjective, in addition to a head component, contains an adjective that qualifies the head (go, debeo, kriv, rid, sed, sitan), and by synecdoche a person in general. In their formation, the most productive is a suffix $-(a) c$, and its competitor is a suffix -ile that is used in folk speeches. In the Macedonian sources, we did not a register the nouns of this semantic-derivative type. Attributive nouns used for nomination of a person according to the intellectual traits and character are also largely motivated by qualitative adjectives in both languages, in whose derivation is dominant suffix $-(a) c /-e c$, 
but also suffixes -ko, -ica, -ile, -nik more often appear. Other formation processes, such as compounding and conversion, represent a peripheral phenomena in derivation of nouns of this semantic type. Motional forms are derived from the usual suffixes -ica and $-k a$, and among them is established a competitive relationship.

From a semantic point of view, it is pointed out to a few polysemantic attributive nouns whose meanings were created by metaphorization (glavonja 1. pej. a. 'čovek velike glave; b. 'glavešina, starešina; 2. term. zoo. 'vrsta leptira, gubar Lymantria dispar'; glavuč 1. pej. 'čovek so golema glava'. 2. 'bogatilivlijatelenčovek; budža; 3. 'čovek na visoka pozicija, funkcioner, direktor).

Žarko S. Bošnjaković

Gordana R. Štasni 